\title{
Sortian an sripntiftr
}

Papers Presented at the Sixtieth Annual Convention

\section{A MERCURY VAPOR LAMP FOR BLEACHING.}

L. N. SAHM, NEW YORK CITY, AND WM. MITTELBACH, BOONVILLE, MO.

The following cut shows the construction of a mercury lamp made by the Hewitt Electric Co., of Hoboken, N. J., that is used for bleaching oils and other articles in the Heller \& Merz laboratories of New York City:

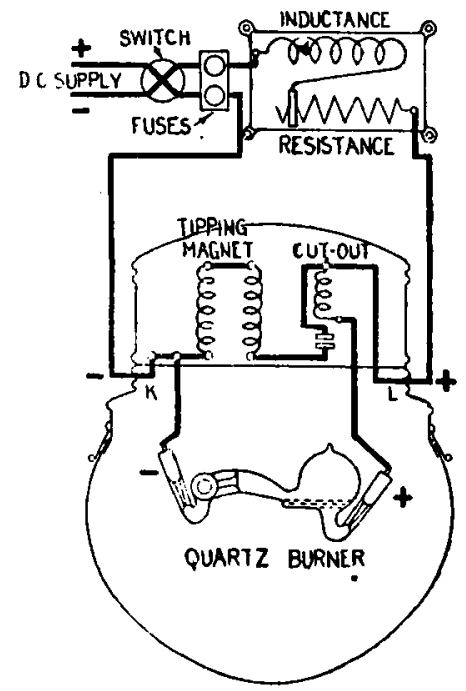

As indicated, the mercury is placed in the large end of the glass apparatus, and quartz crystals in the small end, the whole being exhausted of air. A current of electricity is then passed into the lamp, converting the mercury into vapor, which coming in contact with the quartz produces ultra-violet rays having powerful bleaching properties. In order to handle these most powerful rays, the lamp is suspended under a bell reflector, open at the bottom. Over all a square wooden box is placed having a removable platform or tray so arranged that the object to be bleached is readily removed while the light is completely hidden to the operator. This is necessary for these rays are destructive to the human eye and will quickly destroy it, if exposed directly to the light.

By actual experiment it has been shown that articles can be bleached under this lamp in much shorter time than under the most favorable conditions of the sun's rays.

Some of the fixed oils as poppy, corn, almond, etc., are quickly deprived of coloring matter, an object desired in their use for some purposes. Other pro- 
ducts used in pharmacy can also be treated with this bleaching process, and the lamp be used with practicable results in other directions.

The lamp was invented in Germany four or five years ago, and is being used in that country to a great extent. Its utility is beyond the experimental stage, and ought to be of interest to those working with bleaching processes.

\section{REPORT OF COMMITTEE ON DRUG MARKET, AUGUS'T, 1912.}

Your committee was notified of their appointment so recently that other engagements have prevented some of the members from working and our report lacks their usual valuable contributions. Two conditions attract our attention. First, the statements of Messrs. Roemer, Diekman, Sayre and others that many physicians are dispensing inferior drugs which they purchase at lower than honest market prices. Second, the reports of various state boards that retail pharmacists are either culpably or carelessly guilty of dispensing own make goods of very inferior quality. Simple solutions which should be readily made of standard quality are far below standard. One board finds about 17 percent defective. Another 73 percent, and another 56 percent. Camphorated Oil ranged from 38 percent to 85 percent of official strength. Spirit of Lemon from 1.2 percent to 49 percent of official standard. Spirit of Peppermint from 4 percent to 73 percent, thirty-five convictions being secured. Another authority calls attention to the great variation in the strength of ordinary tinctures as dispensed. Tinct. Belladonna ranged from 1.05 percent to 3.76 percent extractive, a fair average being 1.2 percent to 1.6 percent. Tinct. Digitalis ranged from 1.08 percent to 3.45 percent extractive, a fair average being 3.8 percent to 4.5 percent. Tinct. Gentian Comp. ranged from 1.08 percent to 5.01 percent, a fair average limit being 5 percent to 6 percent. Tinct. Hyosycamus ranged from 1.04 percent to 4.27 percent, a fair average limit being 1.45 percent to 1.75 percent. The average limits of extractive on Tinct. Bellad. and Tinct. Hyoscyamus are based on standard strength in alkaloid. Under present conditions a physician can dispense what he will, but no manufacturer can supply him goods defective in quality or untrue to title, and an active campaign along this line should soon correct the evil.

To guard against the condition in the retail stores the State Associations should caution the proprietors against permitting the manufacture of the simplest products by any one who does not realize the importance of absolute accuracy. In addition, it may be advisable to suggest that the tinctures be examined to assure their being within reasonable limits of strength. The personal element causes trouble in this line as in others. Powd. Sulphate of Iron assaying but 67.5 percent has been shipped by a painstaking, reliable house in error for the U. S. P. Dried Sulphate. Inattention by the proof reader has permitted labels to say what the proprietor did not intend, so that constant vigilance is important to maintain a proper standard in all departments. 
Essential Oils. Many of these oils are systematically adulterated and in a manner which is difficult for the ordinary analyst to detect. The simple determination of physical constants is no longer sufficient to detect adulterants, as products are offered for the express purpose of defeating the ordinary tests. Organic compounds are offered as substances that will "enrich" an oil, that is, raise the alcohol or ester content of an adulterated product. Certain oils are also "standardized," that is, cut down to a definite percentage composition if found to run high in content of the active ingredient. In some instances these practices are more or less openly conducted under the idea that this is a "scientific" method of handling variable products, but the aim of these dealers-obtaining high prices for an inferior product, belies their words. In connection with this report we call attention to the paper by the Chairman of the Committee on the Ash Standard and to the contribution by Dr. Kebler received too late to embody with this report.

It is to be remembered that many of the following cases refer only to individual lots encountered and it is not to be understood that the articles named are usually, or even frequently, inferior.

Acetone. Commercial varies in composition and distills at from $50^{\circ}$ to $70^{\circ} \mathrm{C}$. -W. L. Scovilze.

Acid, Lactic. Usually runs low by U. S. P. method of estimation, nine samples ranging from 72.6 percent to 74.7 percent. If the lactide were all included all samples would show a neutralizing power above 75 percent.-W. L. ScoviLle.

Acid, Phosphoric. Four samples assaying 85 percent were colored brown by a trace of organic matter.-E. L. Patch.

Acid, Tannic. Crude acid, containing traces of gums and resins, is frequently offered. It is compact, heavy and usually dark in color.-W. L. Scoville.

Acid, Tartaric. Lots are found containing traces of copper.-E. L. Patch.

Alcohol. Two lots of cologne spirit darkened and precipitated with Solution of Nitrate of Silver. One lot had considerable color and excess of organic matter.-E. L. Patch.

Ammonium Bromide. Lots were very dirty but met chemical tests of U.S. P. -E. L. Patch.

Antipyrine. One sample slightly off color, melted at $110^{\circ}$. Impurities due to careless manufacturing.-E. H. GANE.

Arnica Root. Is reported heavily mixed with some foreign roots. As high as 75 percent of certain unidentified roots has been found in market samples.-E. H. GANE.

Asafoetida. Seventeen samples gave from 1.8 percent ash to 62.45 percent. From 50 percent to 70 percent alcohol soluble material for most samples, but the range was from 37.6 percent to 76.27 percent.-W. L. Scoville.

There is a marked difference in methods of stating the alcohol soluble contents. Some extract with alcohol, evaporate at low temperature to soft extract, and give the result as alcohol soluble contents. Others extract with alcohol, weigh the 
residue and call the difference alcohol soluble contents. In this method water and all volatile matter is included.

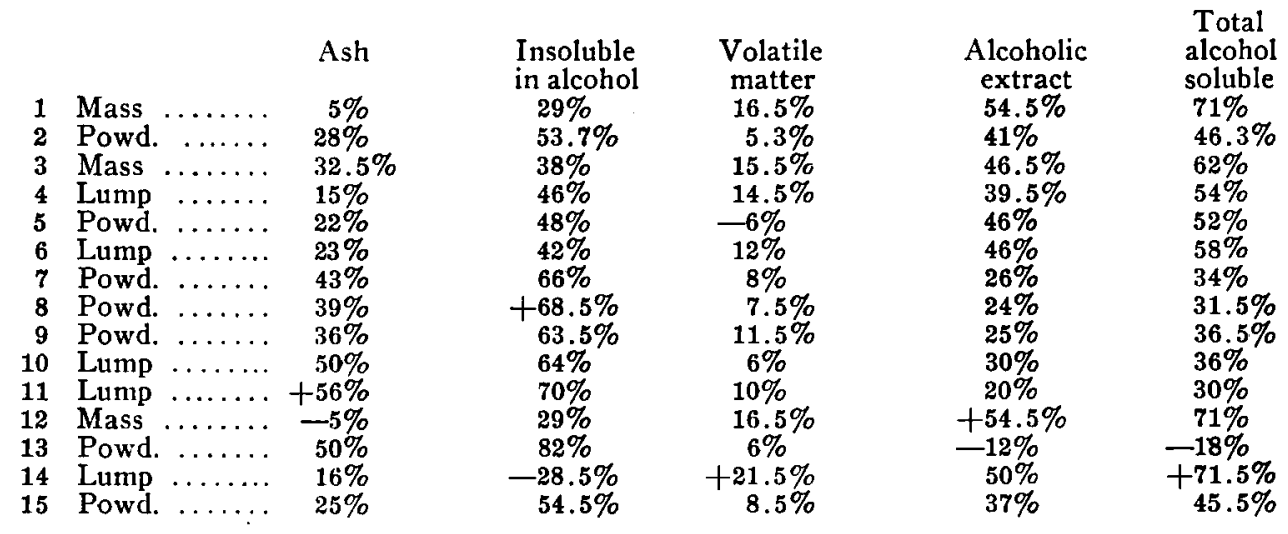

Lots 9 and 15 were labeled to contain 15 percent of Magnesium Carbonate. Lot 8 was labeled to contain 25 percent ash.-E. L. РАтch.

No. 1 ash 6.39 percent, alcohol soluble 43.01 percent. No. 2 alcohol soluble 25.09 percent. No. 3 alcohol soluble 35.52 percent. This contained a large amount of starch. Several lots have been rejected at the port of New York owing to the presence of an excessive amount of terebinthinous oleoresin resembling elemi. Much of this variety has, however, found its way into the market through other ports.E. H. GANE.

Aspirin. Samples had melting point of $130^{\circ}$ to $136^{\circ}$ C.-W. L. Scoville.

Belladonna Leaf. Two-thirds of all samples adulterated with Ailanthus or with poke berry leaves.-Pharm. ERA. ${ }^{1}$ Two lots assayed only 0.309 percent and 0.30 percent. Powders have been offered from abroad consisting of the whole plant powdered. "Italian" belladonna powder has also been offered consisting of the above, mixed with some other leaf adulterant.-E. H. GANE.

Buchu. Long buchu is sometimes adulterated with klip buchu from Diosma fragrans.-WM. MANSFielD.

Burgundy Pitch. Market samples are mainly if not wholly artificial. No house will guarantee to furnish the true article.-E. H. Gane.

Calamine. A fictitious product. Did not contain zinc.-E. L. PAtch.

Calcium Bromide. One lot assayed 97.08 percent and contained trace of bromate. Other lots assayed 82.45 percent, containing excess of water. U. S. P. standard 97 percent.-E. L. PATCH.

Calcium Chloride. Pure-fused. Alkaline reaction.-E. L. PAtch.

Calcium Phosphate Praecip. U. S. P. Labeled U. S. P. Chloride 2 percent did contain 3.1 percent. Other lots contained 0.22 percent, 0.33 percent, 3.9 percent, 2 percent.-E. L. Patch.

Camphor. Specific rotation varies from $41^{\circ}$ to $43^{\circ}$, showing that the amount of adhering oil varies.-W. L. Scoville.

Ceresin. Varies in melting point from $58^{\circ}$ to $65^{\circ}$.-W. L. Scoville.

\footnotetext{
${ }^{1}$ It is probable that most of these samples represent but a few, perhaps only one, importation, so that the proportion stated is very misleading. $-H$. $H$. $R$.
} 
Cinnamic Aldehyde. Adulterated with a mixture of three parts benzyl benzoate and one of cinnamic aldehyde.-Pharm. Era.

Colocynth. Is still found to contain excessive quantities of seeds.-E. H. GANE. Copper Sulphate U.S. P. Many lots contain excess of iron.-E. L. Patch.

$C$ udbear. Varies greatly in coloring power and salt contents. Salt varies from 2 percent to 60 percent.-E. L. Patch.

Dermatol.* One lot contained 46 percent dextrine. One 36 percent bismuth subgallate and the balance potato starch, sand and clay. Another zinc oxide, gypsum, lead chromate and green sand.-Dr. HuBNer.

Ether Acetic. Boils $65^{\circ}$ to $80^{\circ} \mathrm{C}$. in fractioning.-W. L. Scoville.

Euphorbia Pilulifera. One lot offered consisted largely of foreign grasses. Not over one-third was genuine material.-E. H. GANE.

Flaxsed Meal. Contained following percentages of oil: 28.5 percent, 29.65 percent, 25.1 percent, 29.6 percent, 30 percent, 35.2 percent, 34.5 percent, 34.4 percent, 34 percent, 35.6 percent, 35 percent, 32.5 percent, 31 percent.-E. L. РатсH.

Fusel Oil. Is sometimes deprived of the high boiling constituents to which its usefulness is mainly due. One lot distilled over a range of $90^{\circ}$ to $120^{\circ} \mathrm{C}$. only, whereas the valuable and largest fraction should distill at $120^{\circ}$ to $130^{\circ} \mathrm{C}$. - E. H. GANE.

Gelatin. May contain Arsenic.-Apothecary.

Gentian Root. Should yield not over 6 percent of ash and at least 33 percent of water soluble matter. Adulterated powder is easily detected by making these determinations. Gentian for veterinary purposes is frequently adulterated. Two samples gave 2.1 percent and 4.7 percent ash and 12.6 percent and 13.9 percent water soluble matter.-E. H. GANE.

Glycerin. Still difficult to get glycerin which will not develop unpleasant odors in acid solutions. The nature of these bodies is not yet fully divulged, though it is probable that some are of an aldehydic nature.-W. L. ScoviLLE.

Guarana. Assayed 4.25 percent, 4.5 percent, 4.5 percent, 4.2 percent, 4.36 percent, 4.6 percent, 4.4 percent alkaloid. Two percent ash.

Guaiac.

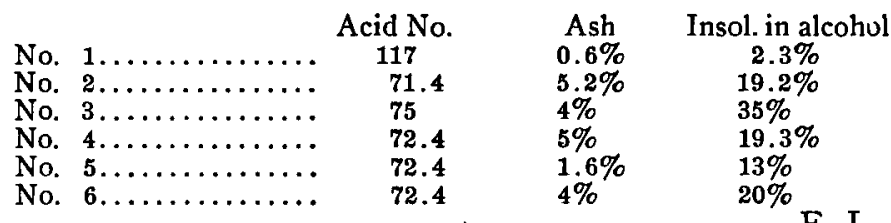

E. L. Patch.

Goldenseal. Two small lots assayed 3.13 percent and 3.6 percent hydrastine.E. H. GANE.

Hyoscyamus. Six lots assayed 0.072 percent, 0.07 percent, 0.108 percent, 0.08 percent, 0.103 percent.-E. L. Patch.

Infusorial Earth. Contains 2 percent to 12 percent of matter soluble in weak alkaline solutions.—W. L. Scoville.

*See Discussion at end of report. 
Ipecac. Four lots assayed 2.07 percent, 1.79 percent, 1.83 percent, 1.82 percent. -E. H. GANe.

Iron Chloride Solution. Assays 11.46 percent, to 13.25 percent Iron.-W. L. SCOVILLE.

Iron Reduced. Assays 88.8 percent to 96.5 percent.-W. L. Scoville.

Iron Sulphate Dried. One lot labeled U. S. P. assayed only 67.5 percent, $\left(\mathrm{FeSO}_{4}\right)_{2}+3 \mathrm{H}_{2} \mathrm{O}$. Other lots, 93.8 percent, 98.78 percent, 89.19 percent, 93.8 percent, 88.12 percent, 82.61 percent, 89.54 percent.-E. L. PATch.

Jalap. Four lots assayed.

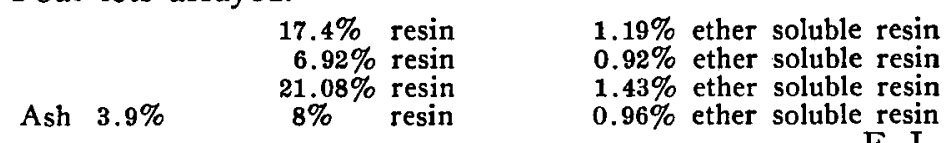

E. L. Patch.

Kieselguhr.

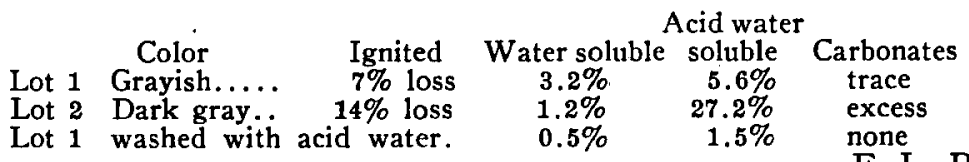

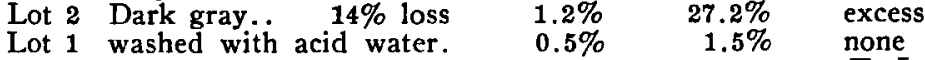

E. L. Patch.

Lavender Flowers. Most of the lavender flowers have been partially exhausted of their oil.-S. K. F. Co.

Licorice Extract Powdered. 35.6 percent to 65.6 percent water soluble matter. -W. L. Scoville.

Lupulin. Four lots gave:

$$
\begin{array}{cr}
\text { Ash } & 12.92 \% \\
\text { " } & 9.46 \% \\
\text { “ } & 12.64 \% \\
& 12.61 \%
\end{array}
$$

$\begin{array}{ccl}\text { Ether Soluble } & \mathbf{5 8 . 1 9 \%} \\ \text { “ } & \text { “ } & \mathbf{6 5 . 6 \%} \\ \text { “ } & \text { “ } & \mathbf{5 7 . 0 9 \%} \\ & & \mathbf{4 4 . 9 4 \%}\end{array}$

E. H. GANE.

Lycopodium. Artificial products consisting of powdered resinous substances are offered in place of the genuine for technical purposes. Some of these closely resemble the true article.-E. H. GANE.

Male Fern Extract. Adulterated with 25 percent castor oil. It contained only 8 percent crude filicin instead of 24 percent.-Merck \& Co.

Malt-Pozwd. Extract. Converts from 30 to 50 times its weight of potato starch.-E. L. Patch.

Magnesium Salicylate. Ignited gives 12 percent MgO.-E. L. РAтch.

Magnesium Sulphate. Contains 0.35 percent to 0.4 percent chloride.-E. L. Patch.

Manganese Oxide. Labeled "precipitated"-Was a black, very gritty powder partially soluble in oxalic acid solution. Was native oxide-E. L. PAtch.

Methylene Blue.-Twenty-three samples yielded 0.04 percent to 3.67 percent ash. Less than half the number gave 0.5 percent ash or less.-W. L. ScoviLle.

Migrainin No. I. Eighty-four percent Antipyrine, 6 percent Citric Acid, 3.5 percent Magnes. Citrate. No. 2-50 percent Antipyrine, 40 percent Acetyl Salicylic Acid, 10 percent starch.-Dr. HuBNER. 
Myrrh. Runs more uniform than formerly; 32 percent to 42 percent alcohol soluble matter. One sample 64.4 percent.-W. L. Scoville.

Nux Vomica. Six lots gave 1.27 percent, 1.49 percent, 1.51 percent, 1.40 percent, 1.36 percent and 1.28 percent Strychnine.-E. H. GANE. Said to be adulterated with ground olive pits. Identified microscopically. Warming with a 0.5 percent solution of paraphenylene diamine a red brown to red color is formed instead of a gray or blackish gray deposit formed with genuine nux vomica.Report Pharm.

Oil Cottonseed. Samples offered as winter pressed solidified when placed in ice chest. Others did not become cloudy.-E. I. Patch.

Oil Lavender. Is adulterated with commercial phthalic ester. It has little odor and a high ester value. A comparatively small quantity added to an oil of low ester value raises this figure considerably.-T. DeLphin.

Oil Lemon. Is mixed with alcohol.-N. A. R. D. Notes.

Oil Wintergreen. No reliable test has yet been published that will identify mixtures of true oil of wintergreen leaf and oil of birch with Methyl Salicylate. Some dealers claim to have such a test but they carefully refrain from giving it publicity.-E. L. Patch.

Olibanum. Ash 20 percent, 30.5 percent, 39.5 percent.-E. L. Patch.

Opium. Case of $220 \mathrm{lbs}$. Product did not resemble ordinary Smyrna opium. Surface was polished with no trace of ordinary wrappings. Some lumps very hard had 5 percent morphine and some only 1-10 percent.-Pharm. ERA.

Oxgall-Powd. Had 3 percent of moisture. Aqueous solution was precipitated by Alcohol. Manufacturer claimed it was purified by U. S. P. method and evaporated in vacuum drier. Unable to make a purified powder that will stand the alcohol test for purified pilular.-E. L. PAтch.

Pancreatin. None will meet the pharmacopœial milk test literally interpreted, namely, that there is no coagulation. The nitric acid with milk unacted upon by pancreatin will produce a firm coagulum or clot. After the action of pancreatin the result is a granular precipitate, not a coagulum. Fresh milk can be peptonized sufficiently for medicinal use without developing more than a slight bitter taste. If carried until decidedly bitter there is no decrease in the amount of granular precipitate.-E. L. PATCH.

Papain. Action on dried beef fibrin. One part digests:

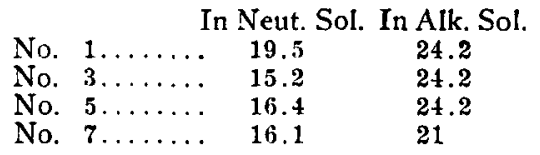

\begin{tabular}{lccc} 
& \multicolumn{3}{c}{ In Neut. Sol. In Alk. Sol. } \\
No. & $2 \ldots \ldots \ldots$ & 18.2 & 19.2 \\
No. $4 \ldots \ldots \ldots$ & 12.1 & 22.9 \\
No. $6 \ldots \ldots \ldots$ & 13.2 & 22.4
\end{tabular}

E. L. Patch.

Phenacetin. Melts at $130^{\circ}$ to $135^{\circ}$ C.-W. L. Scoville.

Pinkroot. Supplies of genuine root are now more easily obtainable, collectors evidently taking more care in gathering the drug.-E. H. GANE.

Pipsissewa. U. S. P. recognizes leaves only. All market lots consist of leaves and stems. Average proportion of leaf is 72 percent.-E. L. PAтch. 
Podophyllin.

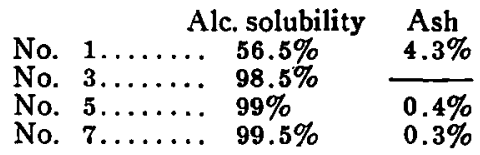

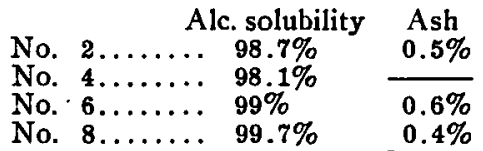

E. L. Patch.

Potassa. Assays 87.3 percent to 90.08 percent.-W. L. Scoville.

Potassium Carbonate. Assays 90.4 percent to 98.35 percent.-W. L. Scoville.

Potassium Nitrate. Chloride in three samples-1.55 percent, 1.55 percent, 3.1 percent.-E. L. Patch.

Quinine Alkaloid. May contain excess of moisture. Assays 68 percent to 87 percent monohydrated quinine. U. S. P. should assay 90.5 percent.-E. L. Patch.

Quinine Tannate. The quinine in different makes ranges from 9 percent to over 30 percent.-Council on Pharm. \& Chem.

Red Saunders-Powd. For some unknown reason shippers wet this down before sending. It contains from 37 percent to 44 percent of water and should not reasonably have more than 5 percent to 7 percent.-E. L. PAtch.

Salophen. Adulterated with 25 percent Acetanilide.-Dr. Hubner.

Santonin. Largely adulterated with acetanilide, boric acid and borax.-AM. DRUG.

Scammony Resin. Adulterated with powdered scammony.-P. Gurgea.

Sodium Phosphate Purified Dried. Clean and white but contained 3.56 percent of anhydrous Sodium Sulphate. Lost 1 percent of water when dried at $100^{\circ} \mathrm{C}$. Another lot labeled in the same way contained 2.58 percent of sulphate. -E. L. Patch.

Sodium Theobromine Salicylate. Substitute for Diuretin.

Lot $112 \%$ of theobromine instead of $40 \%$.

Lot $225 \%$ of theobromine instead of $40 \%$.

Lot $325 \%$ of theobromine sodium and $75 \%$ of sodium salicylate.

-DR. HUBNer.

Spirit Ammonia Arom. Four samples were all right. Forty-six samples varied from standard.-Kentucky State Board of Health.

Spirit of Camphor. Sixteen samples standard and fifty-one below standard.Kentucky State Board of Health.

Spirit Lemon. Five samples tested from 0.1 percent of official to 45 percent. - Mass. State Board of Health.

Spirit Peppermint. Thirty-five samples assayed from 4 percent to 72 percent of official.-Mass. State Board.

Tablet Gum. Was white potato dextrin.-E. L. PAtch.

Thiocol. Adulterated with Sodium carbonate, milk sugar and magnesium sulphate.-DR. HUBNER.

Tinct. Belladonna. Ten samples ranged in extractive from 1.05 percent to 3.76 percent. In alcohol from 26.4 percent to 47.5 percent.-I. W. Pollard.

Tinct. Digitalis. Ten samples ranged in extractive from 1.08 percent to 3.45 percent. In alcohol from 21.6 percent to 40 percent.-I. W. PolLARD. 
Tinct. Hyoscyamus. Ten samples ranged in extractive from 1.04 percent to 4.27 percent. In alcohol from 23.9 to 40.3 percent.-I. W. PolLard.

Tragacanth. Adulterated with India gum, from sterculia urens.-H. C. FULLER.

Wax. Many samples are one-half paraffin, due to the use of artificial comb or foundation.-Dr. KEBLER.

Zinc Oxide. All contains a trace of lead. It is so slight that it can be easily overlooked if the solution in hydrochloric acid is much too strong in acid. If properly acidulated it will come down and can be identified by the confirmatory tests of precipitation as chromate or as sulphate. The U. S. P. digests $1 \mathrm{gm}$. in 10 cc. of diluted hydrochloric acid and $10 \mathrm{cc}$. of water until saturated, removing the undissolved portion by filtration. The amount of zinc oxide specified should always dissolve completely.-E. L. PAtch.

Florence Brand, White Seal, American Oxide. Is a fine, soft powder assaying 99.76 percent oxide of zinc but contains a trace of lead.-E. L. PAtch.

\section{SUPPLEMENTARY REPORT.}

The preceding accounts relate chiefly to drugs actually taken from the American market. The following relate to drugs offered for import, and refused admission by the Federal authorities:

Senna. At a certain season of the year, a form of India Senna known as "Monsoon Senna" is offered. This is senna from the genuine India senna plant, but gathered after the monsoon. Several lots have this year been offered which present prominent differences from the customary appearance. They are narrower, thinner, more acute, on a very slender, almost capillary rachis, of a golden-yellow color, and much inclined to be curved or hollowed out on one edge. They are also more hairy than the original form. These characters agree very well with those of Cassia lanceolata Forskahl, a well-known substitute or adulterant of India senna. This article is now in process of investigation.

Senna siftings, a product consisting of impurities sifted out of Alexandria senna, has been sold as senna. In this product about 75 percent usually consists of true senna leaf in fine pieces which are removed together with the impurities which represent the other 25 percent. Notwithstanding the plain nature of this case, the Government failed to convict of either adulteration or misbranding.

Strophanthus. Much less of this drug is imported than formerly, and the brown seed (S. hispidus) has nearly disappeared from the market. Recently, however, the seed of S. Eminii(?) has been offered for import, both alone and mixed with the genuine. This seed is short, rather blunt, broad and flat, the ridge inconspicuous, and of a pale or whitish color with scarcely a hint of green. Its surface is densely hairy and many of the hairs are disarranged in position, so that they project and give a shaggy or bristly appearance to the seed.

Euphorbia Pilulifera. A very large shipment of this drug was wholly spurious, doubtless by mistake, a different and closely similar species of Euphorbia having been substituted. 
Powdered Drugs. The custom prevails of importing drugs like Buchu, Uva Ursi and Cubebs with the stems admixed, under such names as "Buchu with stems," and then powdering all together and selling as the straight article.

The presence of olive pits in powdered drugs has ceased, at least for the time, and powdered drugs are much more generally pure than formerly.

Gentian. There is a tendency for this (and also Jalap, Inula, etc.) to be dried by an excessive degree of artificial heat, so as to develop a distinct odor of scorching. Jalap is not essentially injured thereby, but the constituents of Gentian and Inula are apt to suffer seriously.

Ergot. This whole subject is in a deplorable condition. Most of the importations of the year have been seriously below grade and the standards of the Pharmacopoia require complete and radical revision.

Correlation of the Pharmacopoeia With the Lazw. This subject also requires radical and thorough action by the Revision Committee. A separate study is being made for discussion at the Denver meeting.

Belladonna. Belladonna leaves have this year been much subject to adulteration with the leaves and tops of Phytolacca, an impurity which is peculiarly difficult of detection.

Recently the adulteration of the root with phytolacca has reappeared.

Rhubarb. This still continues to arrive with hollow or blackish centers, the result of incompletely drying by artificial heat and then leaving the damp central portion to ferment and decay. No test has been devised for detecting this defect in the powdered drug. It seems to respond even better than sound roots to the tests at present in use.

Pareira. Large shipments heavily mixed with stem pieces have been offered.

Ipecac. During the year much of that offered has been called "Panama Ipecac," and has passed for the Carthagena article. There are, however, some slight differences from the latter and the botanical origin of this form is a decidedly interesting problem.

Calamus. Much more of the natural or unpeeled drug, that which ought to be used, is arriving than formerly.

Arnica Root. This drug continues to be much adulterated.

Spigelia. The continued substitution and admixture of spurious roots appears to be due rather to error than intent. It is useless to attempt its determination in any other way than by powdering and examining with a microscope.

Apocynum. No one yet knows which species ought to be used, nor how to identify it if he did.

Berberis. The same may be said of this as of the last.

Aconite. Evidence accumulates that the roots which have been partially exhausted of their starch by the growth of the stem and thus hollow or shrivelled, are richer in alkaloid.

Much "Spanish Aconite" has been offered. It is extremely difficult to determine the species that yield aconite by an examination of the roots, with suff- 
cient certainty. This form is always low in alkaloid and is probably a different species from the official.

Red Cinchona. Most of that sold is not genuine, being either a hybrid bark, with some succirubra parentage, or, ordinary yellow chip bark.

Granatum. There is not a question that the root bark is much richer in alkaloid than the stem bark and their promiscuous sale in indefinite mixtures, should not be tolerated.

Coto. No genuine coto or paracoto has been offered during the year.

Thyme. Various species of Origanum continue to be imported as thyme, the flavor being practically the same.

Marrubium. A large amount which consisted chiefly of Ballota was rejected

Crocus. Under the stimulating influence of rigid enforcement of the standards, an almost marvelous change has occurred in the character of this drug, which is now almost invariably genuine and pure, whereas formerly it was mostly sophisticated.

Matico. The importation of the genuine leaf has been re-established.

Salvia. This drug has to be carefully watched. Several species other than the genuine closely resemble it and are largely offered in late summer.

Buchu. The high price of this article continues to tempt the addition of excessive amounts of stem, sand, etc.

Proprietary articles which are supposed to contain it appear frequently to be made up without it, or with so little that it is utterly ineffective.

Anise. Great quantities containing much weed seed, gravel and pellets of dirt arrive. The ash test should be rigidly applied.

Black Mustard. Large quantities arrive that contain admixtures of colza, rape, charlock, etc., and a good deal is more or less mouldy.

Cardamom Seeds. Nearly all the decorticated cardamom seed is adulterated with spurious seed, the usual amount being about 50 percent. Rigid exclusion of such importations having been practiced, the pure seed is beginning to be offered, though of course at a much higher price.

Aloes. There has been a great improvement in the quality of the Socotrine variety. Moka or Stinking aloes, so abundant last year, has ceased to come and a fine quality is being imported.

Benzoin. The quality of this drug has deteriorated during recent years, the amounts of vegetable impurities being so great as to show clearly that they have been intentionally added.

\section{DISCUSSION.}

H. H. Rusbr.

Dr. H. H. Rusby, New York, asked one correction, which he thought had been made before sending in the report, but which had escaped his notice: It had been stated that more than two-thirds of the samples of belladonna leaves were adulterated with ailanthus. This was true in a certain sense, but it was misleading. For instance, if a very large lot of the drug was sold in London, and got into the hands of a number of different people, when the collector went around and gathered his samples of different dealers, he was really getting samples of that same original lot, and not of different lots. In his opinion, there was nothing like two-thirds of the belladonna leaves imported adulterated, nor one-tenth adulterated, with ailanthus.

Prof. W. A. Puckner, Chicago, said the conmittee in their report had used the trade- 
mark names "dermatol," "thiocol" and "migrainin," controlled by certain firms, and indicated that they were adulterated in different ways. It seemed to him rather remarkable, if true, and highly unethical, that a firm putting out dermatol should at the same time adulterate it in several different ways. He imagined that the terms were used rather loosely, and possibly there were substitutes on the market. Dermatol was the trade-mark name for bismuth subgallate, and he imagined that the different products referred to were not really dermatol.

F. T. Gordon, Philadelphia, thought that in reporting on dermatol, bismuth subgallate was probably intended, as the report seemed to indicate that bismuth subgallate was the subject of investigation.

Dr. J. M. Francis, Detroit, asked what was the title of the report, and the Chair answered that this was the report of the Committee on Drug Market.

Dr. Francis said he did not believe the report was a correct indication of the condition of the drug market. For instance, if a report should be received, based on the work of some statistician, stating that there were a certain number of horse-thieves in Iowa, so many in Idaho, and so many in Tennessee and New York, and a certain number of murders committed in different states, and all were dumped together in one report, a visitor from Mars or some other planet might conclude that this was a terribly wicked world-because of the total absence of proportion. Listening to this report, a man unacquainted with drug conditions in the United States would suppose that the people in this country were suffering from a lamentable state of affairs, and that the trade in crude drugs was absolutely rotten. As a report showing how things were sophisticated, it was interesting, but as a paper showing any true idea of the proportion of drugs sophisticated to pure drugs it was absoluteiy worthless. Dr. Francis said he wanted to go on record as saying, first, that the pharmacists of the United States were enjoying the use of as pure a line of drugs as were used by any civilized nation in the world; and, secondly, that the conditions in the United States drug market today were better than ever before in this country. He believed Dr. Rusby, who was at the head of drug imports at the port of New York, would bear him out in this statement. He did not mean to say that there were no sophistications, and did not mean to say that there was not ample room for reform and improvement; but he did want to state that the druggists of this country had as good drugs on the average as they had anywhere in the world, and that the conditions were improving, and were better than they were five years ago, or perhaps even two years ago. Because of the lack of any statement of proportion, he thought this report was liable to produce a false impression.

Dr. Rusby stated that the real intent of the report was to call attention to certain forms of adulteration that had been seen, and that there was not the slightest intention in this report to show the proportion of adulteration. He was glad Dr. Francis had brought this matter up, but he was compelled to say that conditions were not quite so ideal as Dr. Francis seemed to think. Recently, a drug miller in New York had informed him that he had been asked to bid on several carloads of powdered drugs, but did not do it, because he would be underbid by people in certain cities in parts of the country nearer to the setting sun than New York, and these people would supply these powdered drugs at lower prices than he was able to purchase them for. Dr. Rusby said that when people in trade could not bid against others under such conditions as these, he was satisfied that "something. was going on"--though conditions were better than they were. The idea was to keep right at it, and not let up on these things. It must be remembered that there were people who worked systematically, especially in the matter of powdered drugs, to furnish an adulterated article.

Dr. Albert Schneider, San Francisco, replying to Dr. Francis, agreed that the report was possibly misleading as to percentage of adulterations; but it was not possible to get actual percentages of adulteration. In the section he came from, the West, where he had done his work, the percentage of adulteration of vegetable drugs and powdered drugs, was not far from 50. That did not indicate an ideal condition, to his mind. Nor did he think that conditions had improved at the present time. He had occasion to examine a number of spices in his state laboratory, and upon opening a container labeled pepper of standard quality, he had examined it under the microscope and found it to contain 80 percent of 
ground olive pits. It was a "scientific combination," with the odor of black pepper, and a small amount of capsicum added to give it pungency.

Another case Dr. Schneider told of was that of an examination of some samples of supposed Banda mace for a wholesale spice house in San Francisco. The first sample of mace examined was found to contain about 25 percent of Bombay mace. This was reported to the house, and they became indignant, claiming that they imported only mace of the first quality. They requested a re-examination, and it was again reported that Bombay mace was present. He was finally given a sample of the crude article, from which they declared they had made their powdered mace. This was examined and found to be genuine, first-quality Banda mace. The trouble was finally located, and it was found that they had imported the genuine Banda mace, but before it was shipped to San Francisco it was placed in the hands of a miller in New York City to rough-grind it, and this miller had taken out a certain percentage of the crude Banda mace and substituted the inferior Bombay mace.

A third instance was that of maté. Dr. Schneider said he did not recall a single sample of genuine maté having been in the state laboratory. The samples they had under investigation were highly adulterated, and in some instances contained only a small amount of maté, and in others no trace of it, the substitute being a common variety of mallow leaves. The house sent various samples of maté, which they said they imported through the port of San Francisco. During a recent visit to New York, he had found considerable quantities of the genuine maté, and he had reported to this house that the genuine article was imported and could be had. Only a few days ago he had received another sample of the powdered article for examination, and found it to contain 80 or 90 percent of mallow leaves.

Dr. Francis called attention to the fact that the two gentlemen most severely criticising American drugs were both pharmacologists and botanists, one located at the port of New York and the other at the port of San Francisco. He asked if the opinions expressed referred to the drugs that were commonly ground and sold by the American millers, or to drugs shipped in from other countries that they had turned back.

Dr. Rusby replied that he spoke of certain lots that were received, but nevertheless to a considerable amount. Dr. Francis had told him this morning that nearly all the lupulin had too much sand in it, and showed too much ash. Nearly all this drug that came into New York was free from sand-a good article. Yet when the druggist tried to get it, he had difficulty. The trouble was, that the brewers picked up all the good lupulin, and when there was a large importation so poor that the brewers would not have it, it was pushed onto the retail druggists.

The Chairman said he believed that the point Dr. Francis made concerning this report was well taken, in so far as it was entitled a report of the Committee on Drug Market. He believed that it would carry the idea that this was a report of the condition of the drug market, whereas the report showed that it was a report on adulterated lots of drugs. There were a great many good lots of drugs, of course, of which no mention was made. Mention was made of a few drugs of this class, but that made the report, if anything, still further misleading. This report covered not only drugs, but chemicals, which latter, as a general thing, he had not found to be adulterated, in his personal experience, or that the quality of chemicals was, as a rule, low. He had known of just such instances as were reported by the committee, but they were greatly in the minority. He thought it might not be out of place to have a paragraph in the report explaining the fact that the committee was not trying to give the proportion of adulterated to genuine drugs.

Dr. Rusby said that as the one representative of that committee present, he would assume the authority to make such a change in the report, as he thought it should be made.

Charles E. Vanderkleed, Collingswood, N. J., said he thought the objection was to the name of the committee. If the title of the committee was changed to "Committee on Adulterations," it would exactly cover the field that the committee worked in. If the committee did not consider it was its function to report on the relative proportions of adulterated drugs and chemicals to those of good qualities on the market, he thought it would be well to change the name of the committee as indicated, thus avoiding any misunderstanding as to its function. 